\title{
Editorial
}

\section{Plant Genetics and Gene Study}

\author{
Yuri Shavrukov ${ }^{*}$
}

Flinders University, College of Science and Engineering, Biological Sciences, Adelaide, Australia; E-Mail: yuri.shavrukov@flinders.edu.au

* Correspondence: Yuri Shavrukov; E-Mail: yuri.shavrukov@flinders.edu.au

Academic Editor: Yuri Shavrukov

Special Issue: Plant Genetics and Gene Analysis

OBM Genetics

2020, volume 4 , issue 1

doi:10.21926/obm.genet.2001104
Received: March 04, 2020

Accepted: March 04, 2020

Published: March 04, 2020

In view of current global concerns surrounding the Coronavirus outbreak, the progress of plant research may seem a very minor matter of no great urgency. However, this is only a temporary state of affairs, since plants remain an essential part of Earth's biosphere, producing oxygen from carbon dioxide and supporting the life of all other living organisms. Plants are also a key component of human food and animal feed, providing the vital nutrients and vitamins that fuel every-day life. In addition, plants form the basis of numerous industrial and pharmaceutical production lines of enormous value and importance. Therefore, our life is both based on, and impossible without plants.

The fundamental principles of genetics and gene analysis are the same for all living organisms on our planet. Mendelian laws of classical genetics, and epigenetic effects characterized by unchanged gene structure but altered gene regulation in plants, form the basis of plant life and the inheritance of traits in future generations. Gene structure, the modulation of gene expression, and the genetic regulatory networks governing the relationships among genes are also typical across plant studies and research. Native variability in gene sequences, which may or may not alter gene expression, represents an important instrument to exploit for the development of molecular markers, with Marker-assisted selection, the very valuable practical outcome for crop

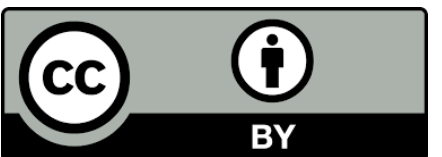

(C) 2020 by the author. This is an open access article distributed under the conditions of the Creative Commons by Attribution License, which permits unrestricted use, distribution, and reproduction in any medium or format, provided the original work is correctly cited. 
breeders. A transgenic approach can help plant scientists to test their resulting hypotheses on gene function using overexpression analyses. These are all very important studies, but also useful complements to modern 'Gene editing' technologies, where a specific nucleotide can be replaced, or a selected genetic fragment changed, entirely at the whim of scientists. Therefore, plants have always been, and will continue to be, favorable biological material for gene study and genetic analysis.

The presented Special Issue reflects a range of modern research within the area of plant genetics and gene study in crops and other plant species. It covers a variety of genetic technologies and scientific approaches that aim to achieve a better understanding of the various aspects of gene analysis in plants and discover more about the molecular mechanisms of key trait genetics in major crops and other commercially important plant species.

We acknowledge Authors submitted manuscripts and welcome those who think to submit their papers soon. We hope that this Special Issue is just the beginning, and that it will be followed on a regular basis by reports of various exciting research findings in the future, reflecting the ongoing progress in plant genetics and gene study.

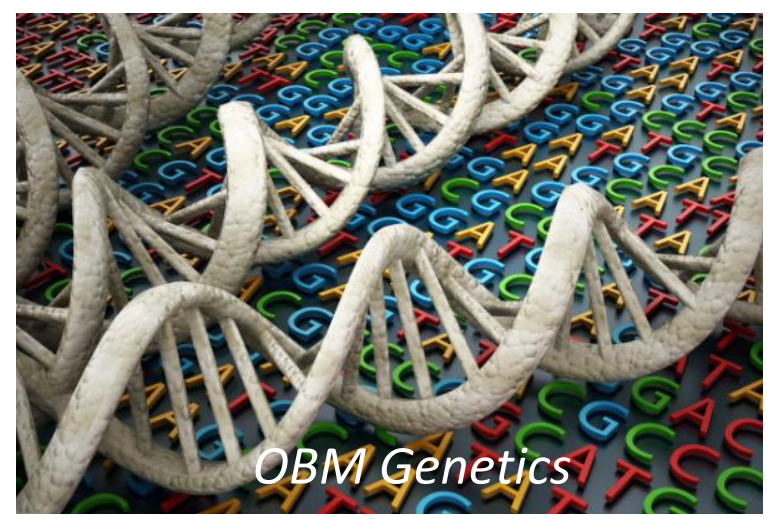

Enjoy OBM Genetics by:

1. Submitting a manuscript

2. Joining in volunteer reviewer bank

3. Joining Editorial Board

4. Guest editing a special issue

For more details, please visit: http://www.lidsen.com/journals/genetics 